\title{
Paleodiversity of the Superfamily Ursoidea (Carnivora, Mammalia) in the Spanish Neogene, related to environmental changes
}

\author{
J. Abella1,2*, P. Montoya ${ }^{3}$, J. Morales ${ }^{2}$ \\ ${ }^{I}$ Institut Català de Paleontologia Miquel Crusafont, Universitat Autònoma de Barcelona, Edifici ICP, Campus de la UAB s/n, \\ 08193 Cerdanyola del Vallès, Barcelona, Spain. \\ ${ }^{2}$ Museo Nacional de Ciencias Naturales, José Gutiérrez Abascal 2, 28006 Madrid, Spain. \\ ${ }^{3}$ Departament de Geologia, Àrea de Paleontologia, Universitat de València, Doctor Moliner 50, 46100 Burjassot, Spain. \\ E-mail addresses: juan.abella@gmail.com (J.A., *corresponding author); pmontoya@uv.es (P.M.); mcnm166@mncn.csic.es (J.M.)
}

Received: 25 May 2013 / Accepted: 3 December 2013 / Available online: 25 February 2014

\begin{abstract}
In the present study we analyse the diversity of the Superfamily Ursoidea during the Neogene of the Iberian Peninsula to further compare it with that of the Neogene of Western Europe to find the different associations of this group. The results indicate that both the diversity and the taxonomy amongst these two regions show important variations, thus letting their interpretation in terms of climatic differentiation. We might relate variations in the abundance of the Ursoidea to the environmental fluctuations taking place during the Miocene and Pliocene. Therefore, they could enable us to reach the assessment of these biogeographical distributions in order to deduce the preferential niches of each different group of Ursoidea.
\end{abstract}

Keywords: Carnivora, Hemicyonidae, Ursidae, Iberian Peninsula, Miocene, Pliocene

Resumen

En este trabajo se analiza la diversidad de la Superfamilia Ursoidea durante el Neógeno de la Península Ibérica, comparándola con la de Europa Occidental de la misma época, con el objetivo de localizar las diferentes asociaciones de los miembros de este grupo. Los resultados indican que tanto la diversidad como la taxonomía varían considerablemente entre las dos regiones estudiadas pudiendo interpretarse en términos de diferenciación climática. Estas variaciones en la abundancia de Ursoidea se pueden relacionar con las fluctuaciones ambientales que tuvieron lugar durante el Mioceno y el Plioceno. Por tanto, nos ayudarán a evaluar las causas de estas distribuciones biogeográficas y a encontrar los nichos preferentes de cada uno de los diferentes grupos de Ursoidea.

Palabras clave: Carnivora, Hemicyonidae, Ursidae, Península Ibérica, Mioceno, Plioceno

\section{Introduction}

The Ursoidea (Hemicyonidae and Ursidae) was one of the most common group of arctoid carnivorans throughout Eurasia and North America during the Neogene (Ginsburg and Morales, 1998; Ginsburg, 1999) with some brief incursions towards the African continent during the Early Miocene, Late Miocene/Early Pliocene and finally during the Pleistocene (Hendey, 1977, 1980; Schmidt-Kittler, 1987; Morales et al., 2005; Geraads, 2008; Werdelin and Peigné, 2010), and a recent migration into South America (via the Isthmus of Panama) during the Pleistocene (Woodburne, 2010). Today this group is restricted to the family Ursidae, subdivided in three subfamilies (Ursinae, Tremarctinae and Ailuropodinae). Besides the genera Ballusia and Ursavus, which we do not yet assign to any of the recent subfamilies in the present work, only the Ursinae and Ailuropodinae were present in the Neogene European fossil record. In extant faunas, only two species have been seen living in the same region. Known are the cases of grizzly bears and American black bears, or polar bears and grizzly bears, but there are other cases like the Asian black bear and the sloth bear in regions of India (Laycock, 1997). In the past, the diversity of the group was high, especially in Europe during the Miocene, declining in the Pliocene. During the Neogene, the superfamily Ursoidea comprised around 45 species, belonging to 13 different genera, with a maximum of seven species per MN biozone. In the Iberian Peninsula the Ursoidea are present since the lower Miocene (MN2) (Ginsburg and Morales, 1995, 1998; Fraile et al., 1997).

The objectives of this study are the following: 1) to interpret the diversity patterns of the Superfamily Ursoidea in the 
Spanish fossil record; 2) to compare the results with the patterns obtained from the Western European record (mainly French and German localities) and so detect differences both in diversity and taxonomic composition of these associations; 3 ) to explore if there is a correlation with climatic changes registered in the geological record of these two areas during the Neogene, and finally, 4) the appraisal of these environmental conditions to assign the major groups of Ursoidea a more precise ecological role. Kostopoulos and Vasileiadou (2006) worked on a similar approach for the Greek localities, where the Ursoidea were much less abundant, than in the Neogene of other parts of Europe.

\section{Systematic approach}

This section should not be taken as an exhaustive revision of the Ursoidea, but only as an introduction of the authors' view of the taxonomic status and a synthesis of the characteristics of this group.

\section{Superfamily Ursoidea Fischer, 1814}

\section{Family Hemicyonidae Frick, 1926}

Extinct Family. Ursoidea characterized by a more primitive and complete dentition than that of the Ursidae, with developed premolars, a lingual cristid in the $\mathrm{p} 4$, relatively sharper and larger carnassials than in the Ursidae, protocone of P4 in mesial position, small talonid in the $\mathrm{m} 1$, upper molars always wider than long and presence of a premasseteric fossa in the more derived taxa.

Subfamily Phoberocyoninae Ginsburg and Morales, 1995

According to Ginsburg and Morales (1995), primitive Hemicyonidae with a tendency towards hypercarnivory and well-developed carnassials (P4 and m1).

Subfamily Hemicyoninae Frick, 1926

According to Ginsburg and Morales (1995), Hemicyonidae with lower carnassials than those of the Phoberocyoninae, longer upper molars with a tendency towards increasing the lingual-distal cingulum turning to be more quadrangular than those found in the Phoberyocioninae, more reduced premolars except for the P4 and an increase in size throughout the Miocene.

Family Ursidae Fischer, 1814

According to Ginsburg (1999), Ursoidea characterized by low and long molars, showing a tendency towards a less carnivorous diet and therefore with hypocarnivore dentition. The genera Ballusia and Ursavus have been herein considered as Ursidae incertaea sedis until a more detailed revision of both of them (especially Ursavus) will be carried out (Abella, research in progress).

Subfamilia Ursinae Fischer, 1814

Emended diagnosis:
Ursidae with derived dentition that tends to reduce both the number and complexity of the premolars; we can also observe a distal elongation of the masticatory surface of the molars. Moreover, the carnassials, and specially the $\mathrm{P} 4$, are so reduced that in species like Ursus maritimus or Ursus thibetanus the protocone of the upper carnassial is almost completely reduced, in other species such as Ursus spelaeus this character is not so evident. The lower carnassial suffers a marked reduction of the trigonid with regard to the talonid, which becomes much longer. They present a quite deep valley between the three cuspids of the trigonid of $\mathrm{m} 1$ that is missing in the other subfamilies of Ursidae, and another one between the trigonid and the talonid, which separates them completely. All but Helarctos malayanus, have relatively long and narrow skulls with wide nostrils.

\section{Subfamily Ailuropodinae Grevé, 1894}

Emended diagnosis:

Medium sized Ursidae with a more primitive general morphology in the dentition than in the Ursinae and Tremarctinae, with less reduced premolars, and well-developed carnassials, except in some teeth of Ailuropoda melanoleuca, which have severe autapomorphies. Relatively short skull, especially in the more recent taxons. Mandibles tend to be relatively short in recent taxa, but they all posses a smooth oval-shaped symphysis. Coronoid, articular and angular process located high in the mandible, and the latter is high and verticalized. Short and conical canines, premolars not reduced in complexity, or even with extra cusps, especially in the lingual wall. Welldeveloped carnassials both in relative size and complexity. Parastyle in P4 well built in the more derived forms. Wide molars, with a square shape, yet somehow elongated, especially the M2 and the $\mathrm{m} 2$. Postcranial skeleton with strong adaptations towards a climbing habit. Presence of a developed radial sesamoid, which in the more derived taxa can be used as a false thumb during the manipulation of the food (mainly from plant origin).

\section{The Ursoidea Fossil Record of Iberian Peninsula and Western Europe}

The diversity data (Fig. 1) have been gathered primarily from the compilations and systematic reviews of Ginsburg and Morales (1995, 1998), Fraile et al. (1997), Ginsburg (1999), Montoya et al. (2001), Abella et al. (2011, 2012), Koufos (2011) and Fortelius (2012). A figure with the temporal distribution of the Ursoidea species throughout the Spanish Neogene is also shown (Fig. 2).

We carried out the similarity analysis on a total of 37 localities with 19 species that occur in the Iberian Peninsula, and 74 localities with 31 species from Western Europe, grouped in MN biozones (Table 1 and Fig. 3).

During the Spanish Neogene we find six main different Ursoidea associations (Table 2), with two gaps without ursoids species. The first gap, which occurred during the lo- 


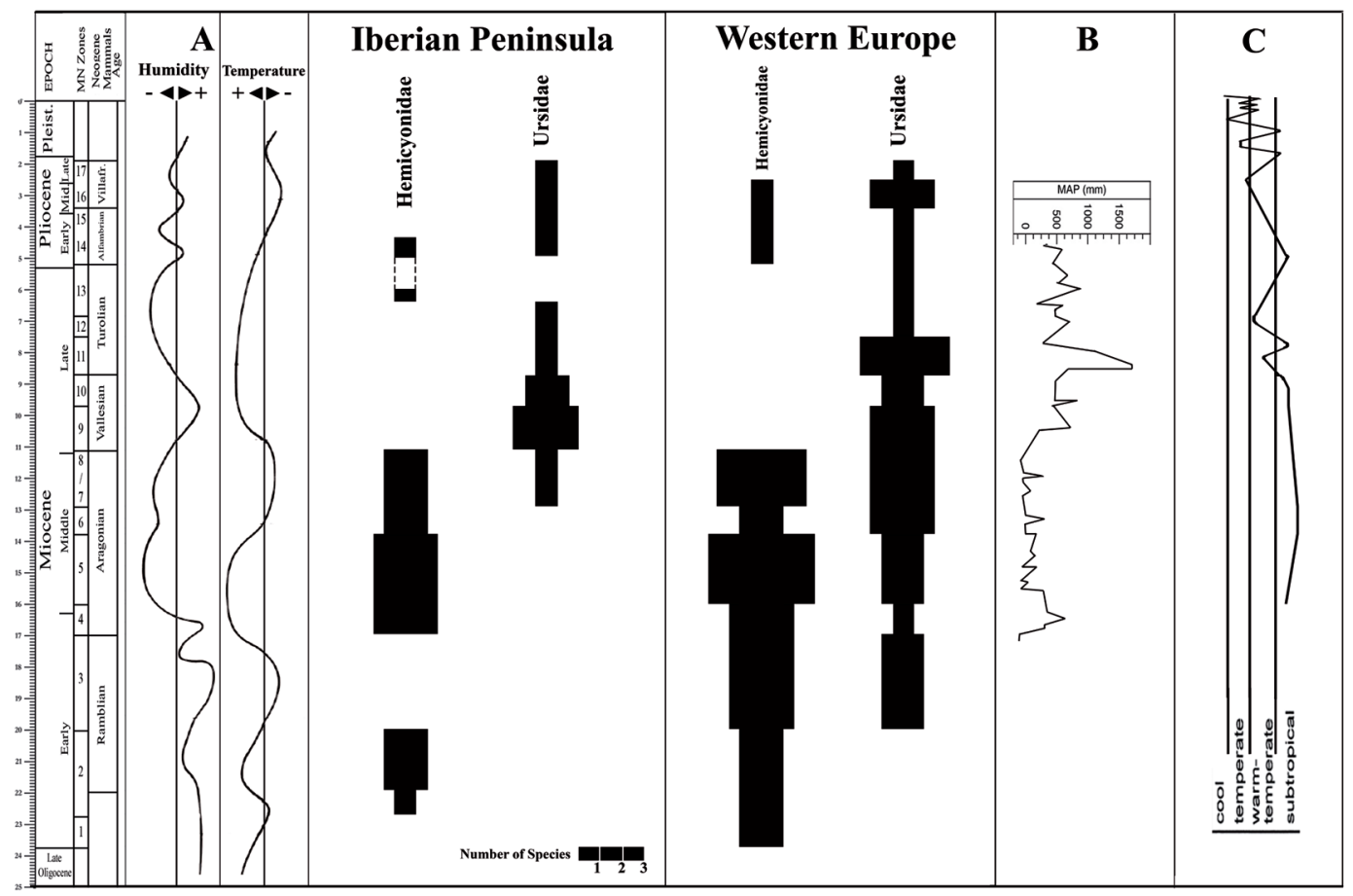

Fig. 1.- Comparison between the number of species of Ursoidea and humidity, temperature and age, during the Neogene of Southwestern Europe and Western Europe. A: Modified from Calvo et al. (1993), B: Modified from Böhme et al. (2011) and C: Modified Paleoclimate curve from Zagwijn and Hager (1987) found in Utescher et al. (2000).

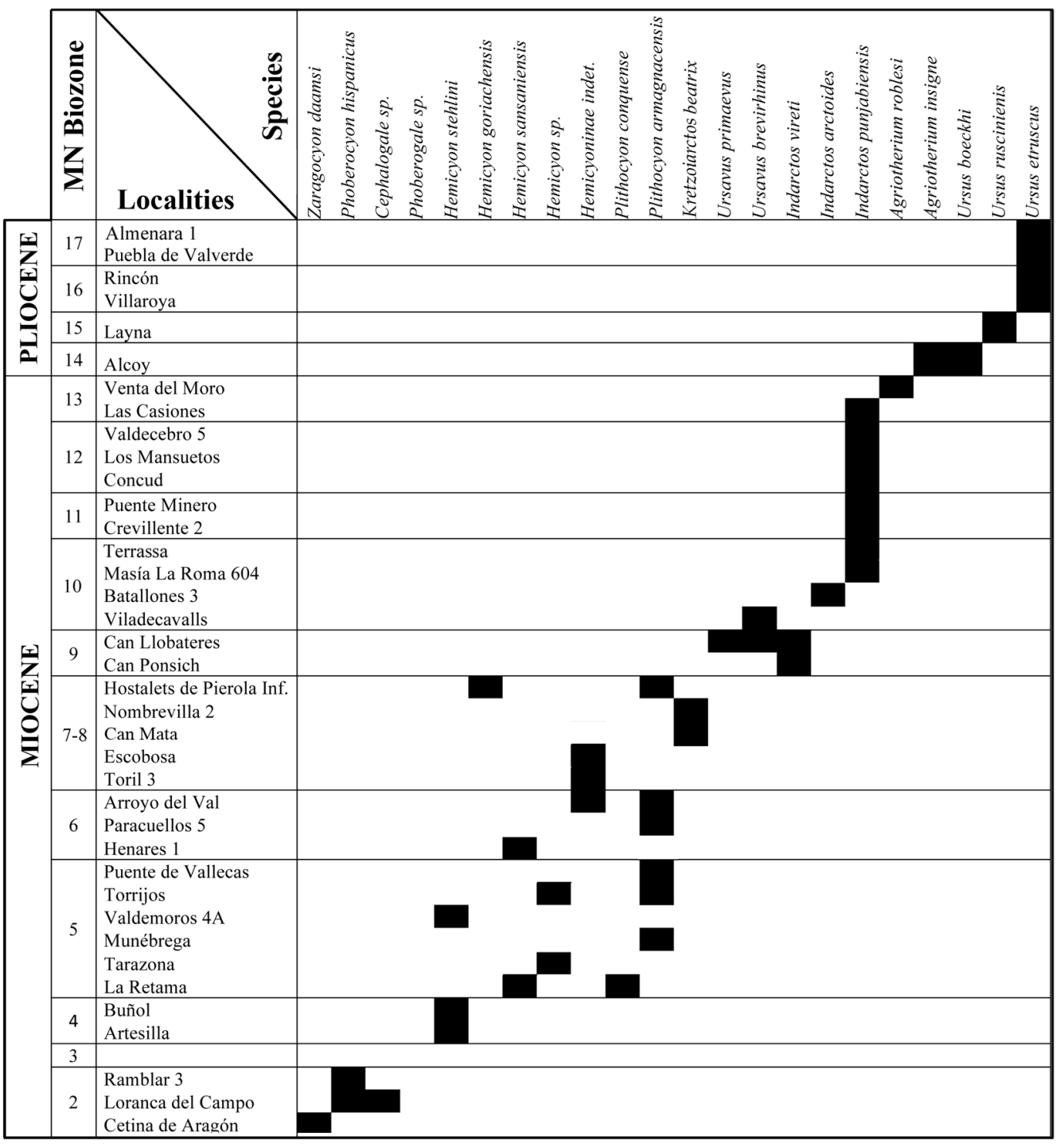

Fig. 2.- Temporal distribution of the Ursoidea species throughout the Neogene. Thrice the MN biozone, name of the taxon and name of the locality (where the remains were found) are shown. The temporal range is not to scale. 


\begin{tabular}{|c|c|c|c|c|c|c|c|c|c|c|c|c|c|}
\hline & 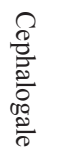 & 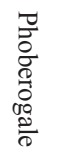 & 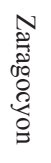 & 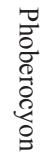 & 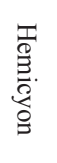 & 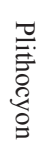 & 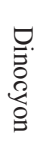 & 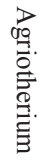 & 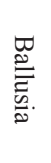 & 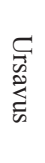 & 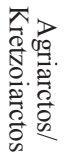 & 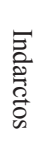 & 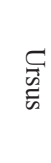 \\
\hline WE1 & 1 & 1 & 0 & 0 & 0 & 0 & 0 & 0 & 0 & 0 & 0 & 0 & 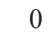 \\
\hline WE2 & 1 & 1 & 0 & 0 & 0 & 0 & 0 & 0 & 0 & 0 & 0 & 0 & 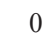 \\
\hline WE3 & 0 & 0 & 0 & 1 & 1 & 1 & 0 & 0 & 1 & 0 & 0 & 0 & 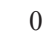 \\
\hline WE4 & 0 & 0 & 0 & 0 & 1 & 1 & 0 & 0 & 0 & 1 & 0 & 0 & 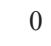 \\
\hline WE5 & 0 & 0 & 0 & 1 & 1 & 1 & 0 & 0 & 0 & 1 & 0 & 0 & 0 \\
\hline WE6 & 0 & 0 & 0 & 0 & 1 & 1 & 0 & 0 & 1 & 1 & 0 & 0 & U \\
\hline WE7/8 & 0 & 0 & 0 & 0 & 1 & 1 & 1 & 0 & 0 & 1 & 0 & 0 & 0 \\
\hline WE9 & 0 & 0 & 0 & 0 & 0 & 0 & 0 & 0 & 0 & 1 & 0 & 1 & 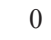 \\
\hline WE10 & 0 & 0 & 0 & 0 & 0 & 0 & 0 & 0 & 0 & 0 & 1 & 1 & 0 \\
\hline WE11 & 0 & 0 & 0 & 0 & 0 & 0 & 0 & 0 & 0 & 1 & 0 & 1 & 0 \\
\hline WE12 & 0 & 0 & 0 & 0 & 0 & 0 & 0 & 0 & 0 & 1 & 0 & 1 & 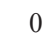 \\
\hline WE13 & 0 & 0 & 0 & 0 & 0 & 0 & 0 & 0 & 0 & 0 & 1 & 1 & 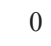 \\
\hline WE14 & 0 & 0 & 0 & 0 & 0 & 0 & 0 & 1 & 0 & 0 & 0 & 0 & 1 \\
\hline WE15 & 0 & 0 & 0 & 0 & 0 & 0 & 0 & 1 & 0 & 0 & 0 & 0 & 1 \\
\hline WE16 & 0 & 0 & 0 & 0 & 0 & 0 & 0 & 1 & 0 & 0 & 0 & 0 & 1 \\
\hline WE17 & 0 & 0 & 0 & 0 & 0 & 0 & 0 & 0 & 0 & 0 & 0 & 0 & 1 \\
\hline WEP & 0 & 0 & 0 & 0 & 0 & 0 & 0 & 0 & 0 & 0 & 0 & 0 & 1 \\
\hline IB2 & 1 & 1 & 1 & 1 & 0 & 0 & 0 & 0 & 0 & 0 & 0 & 0 & 0 \\
\hline IB4 & 0 & 0 & 0 & 0 & 1 & 1 & 0 & 0 & 0 & 0 & 0 & 0 & 0 \\
\hline IB5 & 0 & 0 & 0 & 0 & 1 & 1 & 0 & 0 & 0 & 0 & 0 & 0 & 0 \\
\hline IB6 & 0 & 0 & 0 & 0 & 1 & 1 & 0 & 0 & 0 & 0 & 0 & 0 & 0 \\
\hline IB7/8 & 0 & 0 & 0 & 0 & 0 & 0 & 0 & 0 & 0 & 0 & 1 & 0 & 0 \\
\hline IB9 & 0 & 0 & 0 & 0 & 0 & 0 & 0 & 0 & 0 & 0 & 0 & 1 & 0 \\
\hline IB10 & 0 & 0 & 0 & 0 & 0 & 0 & 0 & 0 & 0 & 0 & 0 & 1 & 0 \\
\hline IB11 & 0 & 0 & 0 & 0 & 0 & 0 & 0 & 0 & 0 & 0 & 0 & 1 & 0 \\
\hline IB12 & 0 & 0 & 0 & 0 & 0 & 0 & 0 & 0 & 0 & 0 & 0 & 1 & 0 \\
\hline IB13 & 0 & 0 & 0 & 0 & 0 & 0 & 0 & 1 & 0 & 0 & 0 & 1 & 0 \\
\hline IB14 & 0 & 0 & 0 & 0 & 0 & 0 & 0 & 1 & 0 & 0 & 0 & 0 & 1 \\
\hline IB15 & 0 & 0 & 0 & 0 & 0 & 0 & 0 & 0 & 0 & 0 & 0 & 0 & 1 \\
\hline IB16 & 0 & 0 & 0 & 0 & 0 & 0 & 0 & 0 & 0 & 0 & 0 & 0 & 1 \\
\hline IB17 & 0 & 0 & 0 & 0 & 0 & 0 & 0 & 0 & 0 & 0 & 0 & 0 & 1 \\
\hline IBP & 0 & 0 & 0 & 0 & 0 & 0 & 0 & 0 & 0 & 0 & 0 & 0 & 1 \\
\hline
\end{tabular}

Table 1. Data matrix used for similarity analysis. Using the 13 Genus of Ursidae, during the Neogene, separated in MN biozones and two regions. IB = Iberian Peninsula. WE $=$ Western Europe. Number shows the $\mathrm{MN}$ biozone, and $\mathrm{P}=$ Pleistocene.

cal biozones A and B (MN3-4, Lower Miocene) (Daams and Freudenthal, 1988), is related to the lack of localities with macromammal remains in the Spanish continental basins. The second is correlated with the so-called "Mediterranean Salinity Crisis" (Latest Miocene). With regard to the Spanish record, where there are significant differences in diversity and composition, the Ursoidea fossil record from Western Europe is continuous.

\section{Results and discussion}

The first Ursoidea appeared in Eurasian faunas during the Oligocene (Qiu, 2003). We find members of this group in Western Europe, since the MN1, with the presence of the genera Cephalogale and Phoberogale (de Bonis, 1973; Ginsburg and Morales, 1995). However, in the Iberian Peninsula due to a lack of localities of the Oligocene-Miocene boundary, the first records are Early Rambian, equivalent to MN2, with Zaragocyon, an endemic genus of the Iberian Peninsula and Phoberogale. In younger localities but still included in the MN2 biozone both Cephalogale and the oldest representatives of Phoberocyon are recorded.

Since the Early Miocene, prior to the appearance of the true bears, the Hemicyonidae show a rapid diversification that made of this group, along with the Amphicyonidae, the predominant medium to large sized carnivorans until the beginning of the Late Miocene, when they became locally extinct, coinciding with the appearance of the Ursidae, Hyaenidae and Machairodontinae felids in the Western Europe faunas. During the Early Miocene, the Ursoidea communities in both the Iberian Peninsula and Western Europe were similar. The presence of tapirs and crocodiles in the deposits (Ginsburg et al., 1987), suggests the existence of one of the most warm and humid periods of the Spanish Neogene (Calvo et al., 1993).

During the MN3, fossil localities with large mammals are very rare in Spain, finding a gap in the record of Ursoidea. However, both the first record of the genera Hemicyon and Plithocyon (Family Hemicyonidae), as well as the first record of an Ursidae, with the genus Ballusia and Ursavus isoire, characterize the Ursoidea record in Western Europe. The climatic data obtained for this period in Western Europe show an increase of humidity and temperature during the MN3 likely related to closer and humid environments, ideal for more hypocarnivore taxa such as Ballusia or Ursavus.

The lower Aragonian (MN4-5) of the Iberian Peninsula is well represented, with plenty of macro-mammal localities. Only the absence of representatives of Ursidae marks a profound difference with Western Europe's fossil record for this period. In this period the Hemicyonidae show a less hypercarnivorous trend in their dentition compared to the Phoberocyoninae, and are also characterized by an increase in their body size.

The presence of the first Ursidae in Europe, with smaller size and a more hypo-carnivorous dentition, may have not affected the diversity of Hemicyonidae. The absence of Ballusia and Ursavus in Spanish sites, considered as hypocarnivore taxa (Ginsburg and Morales, 1998; Fortelius, 2012), may be related to the beginning of the Miocene Climatic Optimum, one of the most remarkable climatic episodes (17-15 Ma) within the Neogene. According to Flower and Kennett (1994), this high temperature climax was followed, between 16.0 and $14.8 \mathrm{Ma}$, by short-term variations in the East Antarctic Ice Sheet volume, the sea level and the deep ocean circulation and in the global climate (Böhme et al., 2011). A major and permanent cooling period occurred between 14.8 and 14.1 Ma, associated to both an increased production of cold Antarctic deep waters and a major growth of the East Antarctic ice sheet. As a result, the meridional temperature gradient increased, the boundaries between climatic zones strength- 


\begin{tabular}{|c|c|c|c|}
\hline & $\begin{array}{l}\text { MN Biozone } \\
\text { interval }\end{array}$ & $\begin{array}{l}\text { Characteristics } \\
\text { of the association of Ursoidea }\end{array}$ & $\begin{array}{l}\text { Maximum Number } \\
\text { of Species }\end{array}$ \\
\hline I & MN2 & $\begin{array}{l}\text { The most primitive members of the Hemicyonidae, from the } \\
\text { Phoberocyininae subfamily, genera Phoberogale and Phoberocyon, } \\
\text { coexist with the less hipercarnivore Hemicyoninae, genus Zaragocyon. }\end{array}$ & $\begin{array}{l}\text { Maximum of two species per } \\
\text { biozone. }\end{array}$ \\
\hline II & MN4-MN6 & Predominance of the Hemicyoninae, genus Hemicyon and Plithocyon. & $\begin{array}{l}\text { Maximum of three species per } \\
\text { biozone. }\end{array}$ \\
\hline III & MN7/8 & $\begin{array}{l}\text { The first Ursidae enter the Iberian Peninsula Agriarctos beatrix through } \\
\text { the North-East basins (Calatayud -Daroca). Some populations of the } \\
\text { genus Hemicyon and Plithocyon remain in the central basins. }\end{array}$ & $\begin{array}{l}\text { Maximum of three species per } \\
\text { biozone. }\end{array}$ \\
\hline IV & MN9 & $\begin{array}{l}\text { The Hemicyonidae become extinct locally. Some Ursidae species become } \\
\text { larger, Indarctos still coexists with small species of the genus Ursavus. }\end{array}$ & $\begin{array}{l}\text { Maximum of three species per } \\
\text { biozone. }\end{array}$ \\
\hline $\mathrm{V}$ & MN10-13 & $\begin{array}{l}\text { The small species of Ursidae disappear. The genus Indarctos becomes } \\
\text { even larger in size, but becomes extinct towards the late Turolian } \\
\text { (MN13). This extinction coincides with the entrance of the giant } \\
\text { Hemicyonidae Agriotherium roblesi to the Iberian Peninsula. }\end{array}$ & $\begin{array}{l}\text { Maximum of three species per } \\
\text { biozone. }\end{array}$ \\
\hline VI & MN14-16 & $\begin{array}{l}\text { The first Ursinae (Ursus boecki) is registered in the fossil record of } \\
\text { Spain. This subfamily will dominate the faunas of Ursoidea throughout } \\
\text { the Pliocene until recent (Ursus arctos). Agriotherium has a slow decay } \\
\text { and finally gets extinct during the MN14-15. }\end{array}$ & $\begin{array}{l}\text { Maximum of two species per } \\
\text { biozone. }\end{array}$ \\
\hline
\end{tabular}

Table 2. Different associations with Ursoidea in the Neogene fossil record of Spain.

ened and the aridification of the mid-latitudes increased (Flower and Kennett, 1994; Böhme 2003; Böhme et al., 2011). Böhme (2004) suggested strong meridional precipitation gradient during this event based on the palaeogeography of the distribution of snakehead fish, and elevated (summer-) precipitation north of the Alpine orogeny (Böhme et al., 2011). These notions have been supported by pollen records (Jiménez-Moreno and Suc, 2007), showing an increase of subdesertic types towards the south, and by the analysis of the body weight structure in mammalian communities (Costeur and Legendre, 2008), indicating a change from densely forested environments in the north to open environments in the south. A temporal difference in the strength of this gradient was reported by Böhme et al. (2006), who showed that the precipitation gradient was stronger in the early Middle Miocene than in the early Late Miocene (but see Bruch et al., 2007 for low gradients during both intervals). In contrast, Fauquette et al. (2006) found, based on pollen spectra of selected time slices, that the European latitudinal precipitation gradient was higher than today and remained unchanged from the Middle Miocene until the Middle Pliocene. Therefore, while in Western Europe there were dense forests, the Iberian Peninsula exhibited drier and more open conditions (Calvo et al., 1993). This fact prevented the Ursidae, considered a group of forest dwellers, from reaching the Iberian Peninsula due to the absence of humid conditions, whereas it favoured the Hemicyonidae.

During the biozone MN6 (late Aragonian) the Iberian Ursoidea record is also characterized exclusively by large sized species of the subfamily Hemicyonidae, while in the rest of Western Europe this group shares their geographical distribution with the less diverse members of the Ursidae family (genus Ursavus). Environmental conditions in the late Aragonian were still very dry and warm (Hernández-Fernández et al., 2003), as they were during the early and middle Aragonian.

During the latest Aragonian (biozone MN 7/8) the first appearance of Ursidae (Kretzoiarctos) is detected in the Iberian Peninsula (Abella et al., 2011, 2012). The record of this first true bear coincides with the progressive decadence of the last Hemicyonidae that become locally extinct during the late Aragonian, and marks a major change in the Ursoidea associations in Spain. This change is also detected for the rodent faunas in the central basins of the Iberian Peninsula (LópezGuerrero et al., 2008) and in the perissodactyl associations with the replacement of Anchitherium by gregarious rhinos. The correlation of both changes with an increase in humidity is most likely (Hernández-Fernández et al., 2003).

A very homogeneous record in the Ursoidea diversity throughout Europe also characterizes the Vallesian (MN910), with the same number of species of in both the Iberian Peninsula and the rest of Western Europe. The oldest record of a large-sized member Ursidae occurs during the early Vallesian (MN9) in the Vallés-Penedés Basin (North East of the Iberian Peninsula) with the species Indarctos vireti and then subsequently most likely migrates North towards other parts of Europe. In the Iberian Peninsula, this first species is substituted by I. arctoides, the first true bear to enter the 


\begin{tabular}{|l|l|l|l|}
\hline Family & Subfamily & Characteristics & Ecological role \\
\hline Hemicyonidae & Phoberocyoninae & $\begin{array}{l}\text { Small-Medium body size. } \\
\text { Hypercarnivore dentition }\end{array}$ & $\begin{array}{l}\text { Hunters of close to open environments. } \\
\text { Similar to extant canids. }\end{array}$ \\
\hline & Hemicyonidae & $\begin{array}{l}\text { Medium-very large body size. } \\
\text { Hyper/meso-carnivore dentition }\end{array}$ & $\begin{array}{l}\text { Hunters and occasional scavengers of open environments. } \\
\text { Similar to extant hyenas or lions. }\end{array}$ \\
\hline Ursidae & Ailuropodinae & $\begin{array}{l}\text { Small-large body size. } \\
\text { Meso/hypocarnivore dentition }\end{array}$ & $\begin{array}{l}\text { Herbivorous to omnivorous forest dwellers, similar to } \\
\text { extant giant pandas, but not so specialised. }\end{array}$ \\
\hline & Ursinae & $\begin{array}{l}\text { Medium-very large body size. } \\
\text { Hypocarnivore dentition }\end{array}$ & $\begin{array}{l}\text { Wide range of diets. } \\
\text { Very adaptable to different environments. }\end{array}$ \\
\hline
\end{tabular}

Table 3. Hypothetical ecological roles obtained for the major groups of the Neogene Ursoidea.

central basins (Abella et al., 2013). The Vallesian is a period of change in both the carnivorans communities, with the first occurrence of large hyenas and machairodontinae felids (Fraile et al., 1997), and in the environmental conditions. The climate suffered a shift towards maximum humidity and high temperatures in all Europe, but especially in some basins of the Iberian Peninsula, allowing the presence of dense and humid forests. This fact would be the main cause of the local extinction of the Hemicyonidae and the presence of various herbivorous ursids of different sizes such as Ursavus and Indarctos.

With the beginning of the Turolian (MN11-13), the diversity of Ursoidea, now restringed only to the Family Ursidae, suffered a gradual fall in the Iberian Peninsula with the extinction of all genera except for Indarctos. Furthermore, this genus was reduced to one only species (I. punjabiensis) in the Spanish record (Montoya et al., 2001), whereas in Western Europe this species coexisted with the mediumsized ailuropod Agriarctos (Kretzoi, 1942). Indarctos punjabiensis showed a tendency towards a less herbivorous diet and postcranial skeleton similar to brown bears (Roussiakis, 2001), which could reflect an adaptation to the more open and arid environments detected in the Turolian of the Iberian Peninsula. However, in Western Europe there is a maximum of humidity present during most of the early Turolian that allowed the presence of smaller and more herbivore taxa, such as Agriarctos

The latest Miocene (MN13) is a quite complicated timespan with many faunal substitutions, extinctions and migrations. While the last members of the genus Indarctos (local biozone M2, Van Dam et al., 2001) are replaced by the Hemicyonidae genus Agriotherium that arrived at the Iberian Peninsula during the biozone M3 of the MN13 (recently dated at 6.23 Ma.; Gibert et al., 2013), the last ailuropod bears begin a relatively quick decay in Western and Central Europe. During the last part of the MN13 there is a small vacuum in the Iberian Peninsula without Ursoidea (between the localities of Venta del Moro and Alcoy, both to the East of Spain).

The severe environmental changes that took place in the peri-Mediterranean region related to the evaporation and partial desiccation of the Mediterranean Sea, the commonly called Messinian salinity crisis (Hsü et al., 1973), were the main cause of this taxonomic shift. This event caused a deep impact in the SW European continental fauna due both to the environmental changes and the immigration of many species from Asia and Africa. The genus Agriotherium is characterized by a huge-size, with quite hypercarnivorous dentition and long limbs (Treves and Palmqvist, 2007), and were more adapted to these new environmental conditions than the more herbivore bears. This genus survives even the Mio-Pliocene limit in both Southwestern and Western Europe, but becomes extinct in the Iberian Peninsula during the MN14. However, some populations of the genus survive until the MN16 in several regions of France (Helbing, 1932; Lacombat et al., 2008). On the other hand, the environmental conditions of Western Europe during this period do not suffer the extreme variations that took place around the Mediterranean Sea so there is no gap in the register of the Ursidae, during the MN13. However, the genus Agriotherium is not registered until the MN14, contemporaneous with the shift between the last Ailuropodinae and the first Ursinae.

This new subfamily, along with the early species of the genus Ursus (U. boeckhi), enters the record during the beginning of the Pliocene (Montoya et al., 2006), a period of dry climate and a tendency towards cold temperatures. The genus Ursus has remained in European faunas until present time, sharing niche with no other member of Ursoidea. Although some populations of Ursus arctos still remain in Western Europe, this species is in serious danger of local extinction.

\section{Conclusions}

The Ursoidea fossil record of Western Europe shows some significant variations in diversity and geographical distribution along the Neogene. We can keep in mind four major steps: 1) Primitives Hemicyonidae (MN1/2). 2) Coexistence of specialized Hemicyonidae with the first Ursidae (MN3 to MN7/8). 3) Local extinction of Hemicyonidae and appearance and spread of Indarctos (MN9 to MN13). 4) Ursidae decline, appearance of Ursus occasionally accompanied by the Hemicyonidae Agriotherium (MN14 to the present). Some significant differences exist when comparing the association of Iberian Peninsula with Western Europe; in particular during the step 2 and in a lesser degree in step 3, whereas steps 


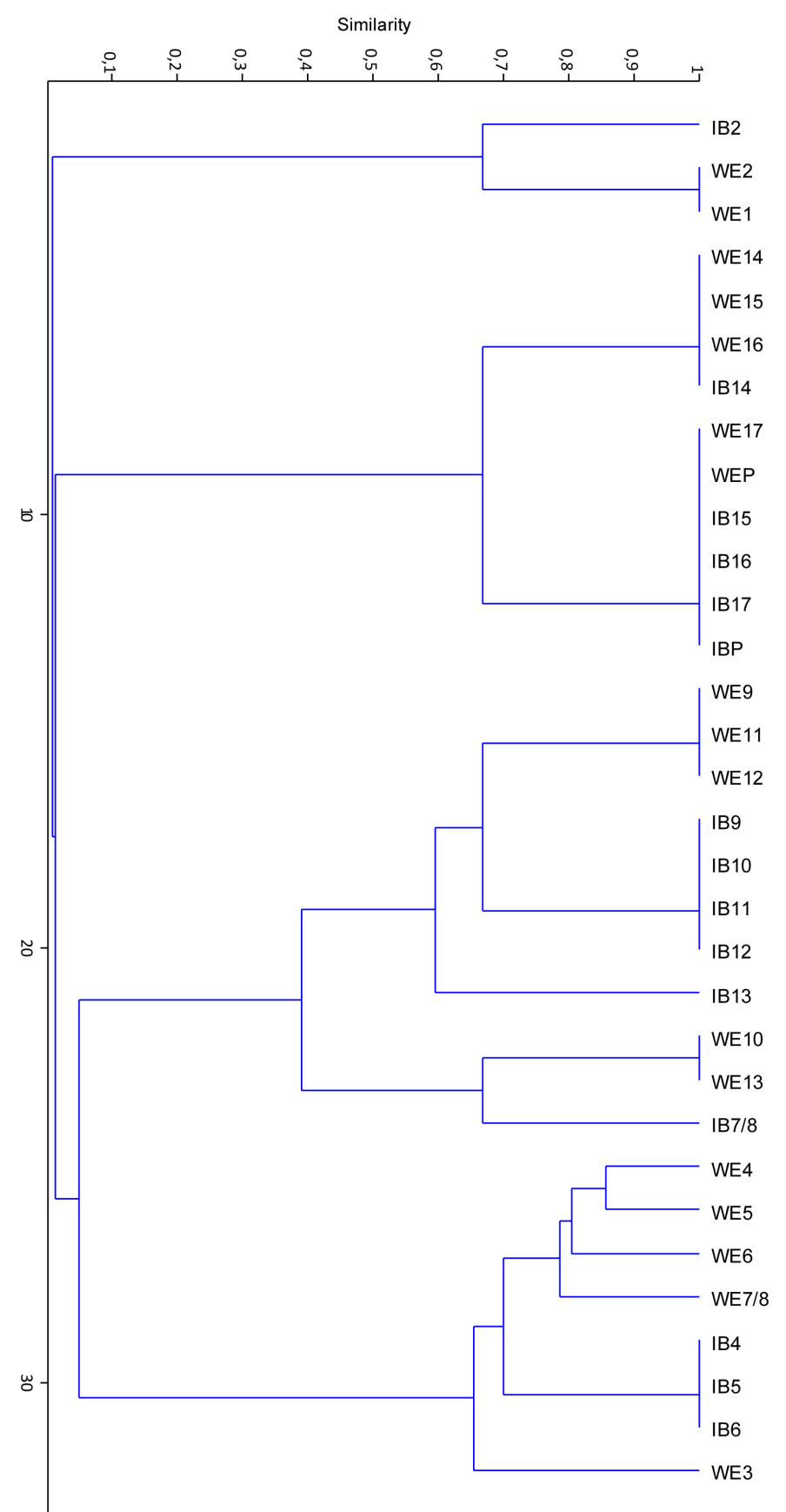

Fig. 3.- Similarity analysis, performed on a total of 37 localities with 19 species for the Iberian Peninsula, and 74 localities with 31 species for Western Europe (grouped in MN biozones). Dice similarity = $2 \mathrm{M} /(2 \mathrm{M}+\mathrm{N})$. Using ' $\mathrm{M}$ ' for the number of matches and ' $\mathrm{N}$ ' for the total number of taxa with presences in just one column. IB=Iberian Peninsula. WE $=$ Western Europe. Number shows the MN biozone, and $\mathrm{P}=$ Pleistocene.

1 and 4 exhibit a high homogeneity. The differences between the two areas can be correlated with the existence of more arid environments in the Iberian Peninsula than in Western Europe.

Based on these data and depending on their biological characteristics and environmental conditions, we can group the Ursoidea into several ecological niches (Table 3). This fact will help the identification of the ecological roles that each taxon of Ursoidea had, thus enabling more extensive paleoecological analyses.

\section{Acknowledgements}

This work has been made possible thanks to the research projects CGL2011-25754 and CGL2011-28681, MINECO (Spanish Government) and the research group BSCHUCM 910607. Thanks are due to Maite Lavandeira for the manuscript revision. We thank Pablo Peláez-Campomanes for his useful help.

\section{References}

Abella, J., Montoya, P., Morales, J. (2011): A New species of Agriarctos (Ailuropodinae, Ursidae, Carnivora) in the locality of Nombrevilla 2 (Zaragoza, Spain). Estudios Geológicos 67(2), 187-191. doi:10.3989/ egeol.40714.182.

Abella, J., Alba, D.M., Robles, J.M., Valenciano, A., Rotgers, C., Carmona, R., Montoya, P., Morales, J. (2012): Kretzoiarctos gen. nov., the Oldest Member of the Giant Panda Clade. PLoS ONE 7(11): e48985. doi:10.1371/journal.pone.0048985

Abella, J., Valenciano, A., Pérez-Ramos, A., Montoya, P., Morales, J. (2013): On the socio-sexual behaviour of the extinct ursid Indarctos arctoides: an approach based on its baculum size and morphology. PLoS ONE 8(9): e73711. doi:10.1371/journal.pone.0073711

Böhme, M. (2003): Miocene climatic optimum: evidence from lower vertebrates of Western Europe. Palaeogeography, Palaeoclimatology, Palaeoecology 195, 389-401. doi: 10.1016/j.palaeo. doi:10.1016/ S0031-0182(03)00367-5.

Böhme, M. (2004): Migration history of air-breathing fishes reveal Neogene atmospheric circulation pattern. Geology 32, 393-396. doi:10.1130/G20316.1.

Böhme, M., Ilg, A., Ossig, A., Kuchenhoff, H. (2006): A new method to estimate paleoprecipitationusing fossil amphibians and reptiles and the Middle and Late Miocene precipitation gradients in Europe. Geology 34, 425-428. doi:10.1130/G22460.1.

Böhme M., Winklhofer, M., Ilg, A. (2011): Miocene precipitation in Europe: Temporal trends and spatial gradients. Palaeogeography, Palaeoclimatology, Palaeoecology 304, 212-218. doi:10.1016/j.palaeo.2010.09.028.

Bonis, L. de (1973): Contribution a l'étude des Mammifères de l'Aquitanien de l'Agenais. Rongeurs-Carnivores-Perissodactyles. Mémoires du Muséum National d'Histoire Naturelle 28, 3-192.

Bruch, A. A., Uhl, D., Mosbrugger, V. (2007): Miocene climate in Europe, patterns and evolution: a first synthesis of NECLIME. Palaeogeography Palaeoclimatology Palaeoecology 253, 1-7. doi:10.1016/j. palaeo.2007.03.030.

Calvo, J.P., Daams, R., Morales. J., López Martínez, N., Agustí, J., Anadón, P., Armenteros, I., Cabrera, L., Cívis, J., Corrochano, A., Díaz Molina, M., Elízaga, E., Hoyos, M., Martín-Suárez, E., Martínez-Salanova, J., Moissenet, E., Muñoz, A., Pérez-García, A., PérezGonzález, A., Portero, J.M., Robles, F., Santisteban, C., Torres, T., Meulen, A.J. van der, Vera, J.A., Mein, P. (1993) Up-to-date Spanish continental Neogene synthesis and paleoclimatic interpretation. Revista de la Sociedad Geológica de España 6 (3-4), 29-40.

Costeur, L., Legendre, S. (2008): Mammalian communities document a latitudinal environmental gradient during the Miocene climatic optimum in Western Europe. Palaios 23, 280-288. doi:10.2110/ palo.2006.p06-092r. 
Daams, R., Freudenthal, M. (1988): Synopsis of the Dutch-Spanish collaboration program in the Aragonian type area, 1975- 1986. In: M. Freudenthal (ed.), Biostratigraphy and paleoecology of the Neogene micromammalian faunas from the Calatayud-Teruel basin (Spain). Scripta Geologica, Leiden, special issue: 3-18

Fauquette, S., Suc, J.-P., Jiménez-Moreno, G., Favre, E., Jost, A., Micheels, A. (2006): Latitudinal climatic gradients in the Western European and Mediterranean regions from the Mid-Miocene (c. 15 Ma) to the Mid-Pliocene (c. $3.5 \mathrm{Ma}$ ) as quantified from pollen data. Geophysical Research Abstracts 8, 07340.

Flower, B.P., Kennett, J.P. (1994): The Middle Miocene climate transition: East Antarctic ice sheet development, deep ocean circulation and global carbon cycling. Palaeogeography, Palaeoclimatology, Palaeoecology 108, 537-555. doi:10.1016/0031-0182(94)90251-8.

Fortelius, M. (coordinator) (2012): New and Old Worlds Database of Fossil Mammals (NOW). University of Helsinki. http://www.helsinki.fi/science/now/. "NOW public release 030717"

Fraile, S., Pérez, B., De Miguel, I., Morales, J. (1997): Revisión de los carnívoros presentes en los yacimientos del Neógeno Español. In: J.P. Calvo, J. Morales (eds.), Avances en el conocimiento del Terciario Ibérico: $77-80$.

Geraads, D. (2008): Plio-Pleistocene Carnivora of Northwestern Africa: a short review. Comptes rendus Palevol 7, 591-599. doi: 10.1016/j. crpv.2008.09.008

Gibert, L., Scott, G.R., Montoya, P., Ruiz-Sánchez, F.J., Morales, J., Luque, L., Abella, J., Lería, M. (2013): Evidence for an African-Iberian mammal dispersal during the pre-evaporitic Messinian. Geology 41, 691-694. doi: 10.1130/G34164.1

Ginsburg, L. (1999): Order Carnivora. In: G. Rössner and K. Heissig (eds.), The Miocene land mammals of Europe. Verlag Dr F. Pfeil, München: 109-148.

Ginsburg L., Morales J. (1995): Zaragocyon daamsi n. gen. sp. nov., Ursidae primitif du Miocène inferieur d'Espagne. Comptes Rendus de l'Académie des Sciences 321, 811-815.

Ginsburg, L., Morales, J. (1998): Les Hemicyoninae (Ursidae, Carnivora, Mammalia) et les formes apparentées du Miocène inférieur et moyen d'Europe occidentale. Annales Paléontolologie 84 (1), 71123. doi:10.1016/S0753-3969(98)80003-7.

Ginsburg, L., Morales, J., Soria, D. (1987): Nouvelles faunes de grand Mammifères d'âge Miocène inférieur dans la partie orientale du basin du Tage (Espagne). Conséquences stratigraphiques. Comptes Rendus de l'Académie des Sciences 305, 229-632.

Helbing, H. (1932): Über einen Indarctos-Schädel aus dem Pontien der Insel Samos. Nebst einen Anhang: Hyaenarctos spec. aus dem Pliocaen von Vialette (Haute-Loire). Mémoires de la Société Paléontologique Suisse 52, 1-18.

Hendey, Q. B. (1977): Fossil bear from South Africa. South African Journal of Science 73,112-116. doi:10.1080/00359197709519922

Hendey, Q. B. (1980): Agriotherium (Mammalia, Ursidae) from Langebaanweg, South Africa, and relationships of the genus. Annals of the South African Museum 81, 1-109.

Hernández-Fernández, M., Salesa, M.J., Sánchez, I.M., Morales J. (2003): Paleoecología del género Anchitherium von Meyer, 1834 (Equidae, Perissodactyla, Mammalia) en España: evidencias a partir de las faunas de macromamíferos. Coloquios de Paleontología Volumen Extraordinario, 1253-1280.

Hsü, K.J., Ryan, W.B.F., Cita, M.B. (1973): Late Miocene desiccation of the Mediterranean. Nature 242, 240-244. doi:10.1038/242240a0.

Jiménez-Moreno, G., Suc, J.P. (2007): Middle Miocene latitudinal climatic gradient in Western Europe: evidence from pollen records. Palaeogeography, Palaeoclimatology, Palaeoecology 253, 208-225. doi:10.1016/j.palaeo.2007.03.040.
Kostopoulos, D.S., Vasileiadou, K. (2006): The Greek Late NeogeneQuaternary ursids in relation to palaeogeography and palaeoenvironment. Scientific Annals, School of Geology Aristotle University of Thessaloniki (AUTH) Special volume 98, 285-292.

Koufos, G.D. (2011): The Miocene carnivore assemblage of Greece. Estudios Geológicos 67(2), 291-320. doi:10.3989/egeol.40560.190.

Kretzoi, M. (1942): Zwei neue Agriotheriiden asu dem ungarischen Pannon. Foldtani Kozlony 72, 350-353.

Lacombat, F., Abbazzi, L., Ferretti, M.P., Martínez-Navarro, B., Moullé, P.-E., Palombo, M.-R., Rook, L., Turner, A., Valli, A.M.F. (2008): New data on the Early Villafranchian fauna from Vialette (HauteLoire, France) based on the collection of the Crozatier Museum (Le Puy-en-Velay, Haute-Loire, France). Quaternary International 179, 64-71. doi: 10.1016/j.quaint.2007.09.005

Laycock, G. (1997): Wilderness Legend Grizzly. NorthWord Press, Minocqua. Wisconsin: $143 \mathrm{p}$.

López-Guerrero, P., Alvarez, M.A., López-Antoñanzas, R., Oliver, A., Peláez-Campomanes, P. (2008): Cricetodontini (Cricetidae, Rodentia) del Aragoniense superior (Mioceno medio) de Nombrevilla 2, (Zaragoza, España). Palentologica Nova 8, 259-271.

Montoya, P., Alcalá L., Morales J. (2001): Indarctos (Ursidae, Mammalia) from the Spanish Turolian (Upper Miocene). Scripta Geologica 122, 123-151.

Montoya, P., Ginsburg, L., Alberdi, M.T., Made, J. van der, Morales, J., Soria, M. D. (2006): Fossil large mammals from the early Pliocene locality of Alcoy (Spain) and their importance in biostratigraphy. Geodiversitas 28 (1), 137-173.

Morales, J., Pickford, M., Soria, D. (2005): Carnivores from the Late Miocene and basal Pliocene of the Tugen Hills, Kenya, Revista de la Sociedad Geológica Española 18, 39-61.

Qiu, Z. (2003): Dispersal of Neogene Carnivorans between Asia and North America. Bulletin of the American Museum of Natural History 279, 18-31. doi:10.1206/0003-0090(2003)279<0018:C >2.0.CO;2

Roussiakis, S. (2001): Postcranial remains oflndarctos atticus (Ursidae, Mammalia) from the classical locality of Pikermi (Attica, Greece), with a description of the front limb. Senckenbergiana lethaea 81(2), 347-358. doi:10.1007/BF03042789.

Schmidt-Kittler, N. (1987): The Carnivora (Fissipeda) from the lower Miocene of East Africa. Palaeontographica A197, 85-126.

Treves, A., Palmqvist, P. (2007): Reconstructing Hominin Interactions with Mammalian Carnivores (6.0-1.8 Ma). In: S.L. Gursky and K.A.I Nekaris (eds.), Primate anti-predator strategies. Springer, New York: 355-380. doi:10.1007/978-0-387-34810-0_17.

Utescher, T., Mosbrugger, V., Ashraf, A. R. (2000): Terrestrial Climate Evolution in Northwest Germany Over the Last 25 Million Years. Palaios 15(5), 430-449. doi:10.2307/3515514.

Van Dam, J.A., Alcalá, L., Alonso Zarza, A., Calvo, J.P., Garcés, M., Krijgsman, W. (2001): The upper Miocene mammal record from the Teruel-Alfambra region (Spain). The MN system and continental stage/age concepts discussed. Journal of Vertebrate Paleontology 21(2), 367-385.

Werdelin, L., Peigné, S. (2010): Carnivora. In: L. Werdelin and W.J. Sanders, (eds.), Cenozoic Mammals of Africa. University of California Press, Berkeley, Los Angeles, London: 603-657.

Woodburne, M. O. (2010): The Great American Biotic Interchange: Dispersals, Tectonics, Climate, Sea Level and Holding Pens. Journal of Mammal Evolution 17(4), 245-264. doi: 10.1007/s10914-0109144-8

Zagwijn, W., Hager, H. (1987): Correlation of continental and marine Neogene deposits in the South-eastern Netherlands and the Lower Rhine district. Mededelingen Werkgroup Tertiaer Kwartaer, Geologie 24, 59-78. 